\title{
UCCRI BRRLANDD
}

\section{INFORMATION CLEARANCE FORM}

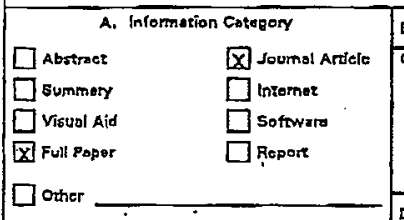

E. Requlrad Information

B. Douument Number HNF-3105-FP

C. Title

Integrating a Life-Cycle Assessment with NEPA: Does. it Make Serce Sese?

D. tmemar addrea charles h ecclestonerl.gov

1. Wocument potontiolly clarbified? $\mathrm{X}$ No $\square$ Yos mandatoRn

If Yos ADC Signafuto Required

$\square$ No $\square$ Yos ctarsifiod

2. Internal Reviow Requlred7

if Yos, Document slghatureg Bclow

[X] No $\square Y_{\text {No }}$

- Countel

Program

3. Referenoet in the Infomation sxe Appllod Technology

Expar Controlled Infermation
XNo $\square$ res

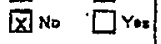

14. Does Information Comain the Following: (MANDATORY)

ง. Now or Naval (Perentablo) subjeot Matrot? $\square$ No $\square$ Yor

It "Yos"., Dleclosure.Nos:

b. Infarmation Recelvad in Confidence, such as Proprietary ondlor Invertions?

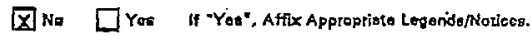

E. Copyrights? $\mathrm{X}$ No $\square$ Yos If "Yox", Aruch Pemission.

6. Trademake? $X$ No $\square$ Yes If -Yeo:. Idendify In Document.

6. Is Informotion refutring submisston to OSTI7 $\square$ No QYFos

If Yos UC- 2000 and B\&R-EUU7OYOLOO

6. Relessa Laval? 通 Pụblia $\square$ Limited

7. charge code R1A63 HAN $7 / 800^{\circ}$

F. Complete for s joumal Articls

1. Teke of Joumal Environmental Journal

a. Complete for a Presentation

1. Tidlo for Conference or Mosting N/A

2. Group sponcering $N / A$

3. Date of Conferenes

5. Wal Information be Publiohed in Procesdinge? $\square$ Na $\square$ Yea . 6. Will Materid bo Hanbed Our? $\square$ No $\square$ Yc5

C. Auther/Requacior

Print and signt

1.'Rovisware

. Otice of Extemal Aftaita

DOE.RI

国

S. A WoodV - akprose

Reiponeible Menquer

gther

Onter

$\square$

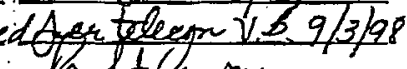

Pubric YN (H N, zompleto J)

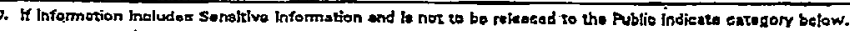
$\square$ appliod Toshnology
प] Protoeted CRADA
D Parconalprivato
Depar Conuolled
$\square$ Proprieteir.
$\square$ Buaineog-Sensitive
$\square$ Prosumani-Sansitivo
$\square$ Pradocisional
Q Prentakle
$\square$ other ispoeity)

Guent

X. If Addribnal Comments, Plepse Areeh Sopapate Gheet

Y / N

(P) $\mathrm{N}$

(1)/ N

$\mathrm{Y} / \mathrm{N}$

$Y / N$ 


\section{Integrating a Life-Cycle Assessment with NEPA: Does It Make Sense?}

Prepared for the U.S. Department of Energy

Fuon Davas. MANword, avc.

Richland, Washington

Hanford Management and Integration Contrector for the U.S. Department of Energy under Contract DE-AC06-96RL13200

Copyrght Lioenee By acceptance of this article, the publisher and/or necipient acknowledges the U.S. Government's right to retein a nonexclusive, royalty-free license in and to eny copyright covering this paper. 


\section{Integrating a Life-Cycle Assessment with NEPA: Does It Make Sense?}

\section{H. Eccleston}

Waste Management Federal Services of Hanford, Inc.

Date Published

August 1998

To Be Published in

Environmental Journal

Prepared for the U.S. Department of Energy

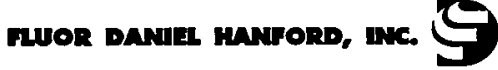

P.O. Box 1000

Richland, Washington

Hanford Management and Integration Contractor for the

U.S. Department of Energy under Contract DE-AC06-96RL13200

Copyright Loense By acceptance of this article, the publisher and/or recipient acknowledges the U.S. Govermment's right to retain a nonexclusive, royahy-free license in and to any copyright covering this paper. 


\section{RELEASE AUTHORIZATION}

Document Number: $\quad$ HNF-3105-FP

Document Title:

Integrating a Life-Cycle Assessment with NEPA: Does It Make Sense?

This document, reviewed in accordance with DOE Order 1430.1D, "Scientific and Technical Information Management," and DOE G 1430.1D-1, "Guide to the Management of Scientific and Technical Information," does not contain classified or sensitive unclassified information and is:

APPROVED FOR PUBLIC RELEASE

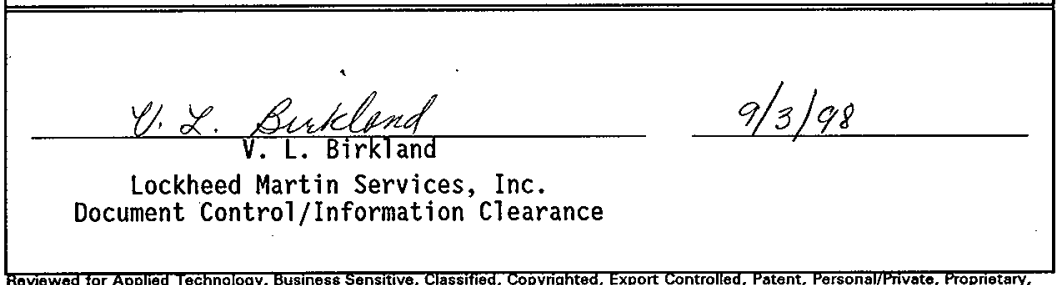

Protected CRADA, Trademark, Unclassified Controlled Nuclear Information.

COPYRIGHT LICENSE NOTICE. By acceptance of this article, the publisher and/or recipient acknowladtes the U.S. Government's right to retain a nonexclusive, royalty-free license in and to any copyright covering this paper.

LEGAL DISCLAIMER. This report was prepared as an account of work sponsored by an agency of the United States Government. Neither the United States Govemment nor any agency thereof, not any of their employees, nor any of their contractors, subcontractors or their employees, makes any warranty, express or implied, or sssumes any legsi liability or responsibility for the accuracy, completeness, or any third party"s use or the results of such use of any information, apparatus, product, or process disclosed, or represents that its use would not infringe privately owned rights. Reference herein to any specific commercial product, process, or service by trade name, trademerk, manufacturer, or otherwise, does not necessarily constitute or imply its endorsement, recommendation, or favoring by the United States Govemment or any agency thereof or its contractors or subcontractors. The views and opinions of authors expressed herein do not necessarily state or roflect those of the United States Govemment or any agency thereof. This report has been reproduced from the best available copy. Printed in the United States of America. 


\title{
INTEGRATING A LIFE-CYCLE ASSESSMENT WITH NEPA
}

\author{
Does it make sense?
}

\author{
Charles H. Eccleston
}

\begin{abstract}
The National Environmental Policy Act (NEPA) of 1969 provides the basic national charter for protection of the environnent in the United States. Today NEPA has provided an environmental policy model which has been emulated by nations around the world. Recently, questions have been raised regarding the appropriateness and under what conditions it makes sense to combine the preparation of a NEPA analysis with the International Organization for Standardization (ISO) - 14000 standards for Life-Cycle Assessment (LCA). This paper advances a decisionmaking tool consisting of six discrete criteria which can be employed by a user in reaching a decision regarding the integration of NEPA analysis and LCA. Properly applied, this tool should reduce the risk that a LCA may be inappropriately prepared and integrated with a NEPA analysis.
\end{abstract}

Is the requirement for performing the International Organization for Standardization (ISO) -14000 consistent Life-Cycle Assessment (LCA) compatible with the requirements for preparing an Environmental Impact Statement (EIS)? Specifically, under what conditions does it make sense to perform an integrated EIS/LCA? This question was recently the topic of a panel discussion at the $23^{\text {rd }}$ annual conference of the National Association of Environmental Professionals.

Preparation of a LCA on an action of narrow scope can be challenging, time consuming, and costly. Clearly, prudence should be exercised in reaching a decision to perform an integrated LCA/EIS analysis. This paper addresses the following question:

Under what circumstances (if at all) does it make sense to integrate a LCA with an EIS? More specifically, are there specific criteria that one could use in determining if an EIS action is amenable to a LCA?

Before delving into this question, let us briefly review the requirements of the National Environmental Policy Act (NEPA) of 1969.' Later, a tool will be presented for assisting decisionmakers and practitioners in answering this question. The decisionmaking tool that is presented might apply outside of the United States. Especially, where other 
nations have adopted environmental policies modeled after NEPA and that contain their own environmental impact assessment requirements.

\section{NATIONAL ENVIRONMENTAL POLICY ACT}

In enacting NEPA, the United States Congress established the first national policy enacted for preserving and safeguarding the environment for future generations. Since 1969, NEPA's precedent has served as a global model.

Had NEPA simply been limited to establishing a national policy, it may have been a 'paper tiger.' Such was not the case. Beyond propagating a national policy, NEPA also established a systematic framework for factoring environmental consequences of potential actions into the federal decisionmaking. The NEPA planning process can be conceptualized as consisting of three distinct levels of environmental examination which are described below:

- Categorical Exclusions

- Environmental Assessments

- Environmental Impact Statements

As indicated by the first bullet, some actions fall into predetermined categories, which have been previously examined and found to have no significant environmental impacts. Such actions can be categorically excluded from further environmental examination with respect to NEPA requirements. An Environmental Assessment (EA) can be prepared where an action can not be categorically excluded and where there is uncertainty as to whether the action would result in significant environmental impacts. An EIS must be prepared if the EA concludes that the action would significantly impact the environment. Specifically, an EIS must be prepared for

\section{... all major federal actions significantly affecting the quality of the human} environment...

With respect to other U.S. environmental laws and regulations, NEPA is unique. Virtually every other environmental statute and regulation can be viewed as a type of permit or approval. Permits and approvals restrict the types of activities that might take place, and establish how actions may be carried out within proscriptive limitations, whereas NEPA decisions do not. As a planning process, NEPA forces decisionmakers to consider potential significant impacts early in the federal agency planning process before a decision is made to pursue a particular course of action. The EIS must rigorously evaluate the direct, indirect, and cumulative impacts of a proposal and the alternatives that would reduce or avoid environmental damage. An EIS must also evaluate any irreversible and irretrievable commitment of resources, and mitigation measures. 
Decisionmakers must consider the results of this analysis in making a final decision to pursue a course of action.

\section{LIFE-CYCLE ASSESSMENT}

Life-cycle assessment is a valuable 'cradle-to-grave' accounting tool for use in identifying and mitigating negative environmental/economic impacts of products and processes. A LCA provides an effective methodology for detecting resource inefficiencies and major sources of waste generation. The ISO-14000 series of standards has been designed to guide organizations towards more environmentally responsible practices. As defined in ISO 14040: Environmental Management - Life Cycle Assessment - Principals and Framework, the LCA is composed of four phases.

The first phase, described in ISO-14040, provides the definition of scope and goals for a LCA. Phase two, which is detailed in ISO-14041, describes the LCA inventory analysis (discussed in ISO-14040) which is used to quantify the inputs and outputs of a product or process. Phase three, which is detailed in ISO-14042, provides guidance on performing a LCA impact assessment for evaluating the magnitude of potential environmental impacts of a product or system based on the LCA inventory analysis. The fourth phase, which is detailed in ISO-14043, provides guidance for interpreting the results of the LCA.

\section{CRITERIA FOR DETERMINING IF A LIFE-CYCLE ASSESSMENT SHOULD BE INTEGRATED WITH NATIONAL ENVIRONMENTAL POLICY ACT}

Based on the purpose and regulatory requirements of NEPA, the following criteria are proposed for determining if a federal action is a candidate for a combined NEPA/LCA.

\section{Significant Impacts}

As noted earlier, an EIS is prepared on federal proposals that might "significantly" affect the environment. Requiring a rigorous analysis of potential actions, alternatives, and their significant impacts -- an EIS is a large undertaking. Categorical exclusions (CX) and EA's require less effort.

The principal reason for preparing an EA, for example, is to "Briefly provide sufficient evidence and analysis for determining whether to prepare ... " an EIS. ${ }^{3}$ The recommended page length of an $\mathrm{EA}$ is between 10 to 15 pages. For this and other reasons that will become apparent later, an EA clearly does not appear to provide a practical forum or mechanism for performing a LCA analysis. Since little or no documentation is required, the same logic is true for a CX. 


\section{Reasonably Foreseeable Impacts}

With respect to NEPA, the courts have generally concluded that the analysis of environmental impacts is governed by the Rule of Reason. That is to say, environmental impacts need only be evaluated to the extent they are deemed reasonably foreseeable. The requirement to investigate impacts does not extend to impacts deemed remote or speculative.

\section{Ripe for Decision}

While the scope of the EIS inquiry is normally much broader, a LCA generally requires a level of assessment which is generally more detailed than is required for an EIS. A LCA should only be performed if the proposal has matured to a stage where information is available to support an analysis. Because of the need for more detailed information, a LCA might need to be performed at a later stage in project development then is necessary for an EIS.

The NEPA regulations recognize such limitations as they encourage federal agencies to tier their EISs to focus on actual issues:

... ripe for decision at each level of environmental review. ${ }^{4}$

If a particular action or process has not advanced to the stage where it is ripe for decision (e.g., analysis) it may be deferred to a later stage when more information is available. It may be appropriate to incorporate a LCA if a NEPA analysis is prepared later and tiered from an early EIS. In such cases, it may be appropriate to prepare a LCA analysis even if the tiered document is an EA.

\section{National Environmental Policy Act's Intent - An Environmental Planning and Decisionmaking Process}

NEPA is a planning and decisionmaking process. As indicated in the regulations:

... The NEPA process is intended to help public officials make decisions that are based on understanding of environmental consequences, and take actions that protect, restore, and enhance the environment... ${ }^{5}$

Use the NEPA process to identify and assess the reasonable alternatives to proposed actions that will avoid or minimize adverse effects of these actions upon the quality of the human environment. ${ }^{6}$ 
Use all practical means ... to restore and enhance the quality of the human envirnmment and avoid or minimze any possible adverse effects of their actions upon the quality of the human environment. ${ }^{7}$

Consistent with this direction, a LCA might be justified if it has a potential to improve the agency's final decision. ${ }^{8}$

\section{Unresolved Conflicts}

In complying with NEPA, agencies are required to:

... study, develop, and describe appropriate alternatives to recommended courses of action in any proposal which involves unresolved conflicts concerning alternative uses of available resources..."

Many LCA studies are conducted to evaluate unresolved conflicts in the use of environmental resources. A LCA, therefore, might be justified if it would help settle or clarify unresolved conflicts in the commitment of environmental resources.

\section{A Clear Basis for Choice Among Options}

The section on alternatives is the "heart" of the EIS. In describing the proposal and alternatives, this section supports the ultimate goal of:

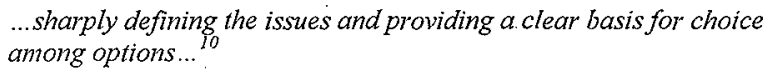

A LCA might be justified if it could help to define the issues thus providing the decisionmakers with a clear basis for making a reasoned choice between alternatives.

\section{CONSTRUCTING A DECISIONMAKING TOOL}

At this point, criteria have been identified for determining if and when it makes sense to integrate a LCA with NEPA. Let us now explore how these criteria can be assembled to construct a tool for making such decisions. A decisionmaking tool consisting of six distinct tests is presented in Figure 1.

\section{Applying the Tool}

Application of the decisionmaking tool is initiated by the rounded first rectangle depicted in Figure 1. The user reviews a proposal (e.g., alternative, subprocess, mitigation 
measure) to determine if an integrated NEPA/LCA analysıs is warranted. A series of six distinct tests are uced to ascist the user in reaching a decision

The first three tests (beginning with the criterion labeled: "Would the integrated analysis involve significant issues or impacts?") are screening criteria. A "No" response to any one of the first three tests is sufficient to reach a determination that an integrated NEPA/LCA analysis is not warranted.

If the response to the first three tests are all "Yes," the user proceeds to the second rectangle labeled with the following question: "Is there a reasonable chance that the LCA could...?" This question is followed by three additional tests. A response of "Yes" to any one the three tests, is sufficient to support a determination that the proposal or aspect to the proposal may benefit from an integrated NEPA/LCA analysis.

A response of "Yes" only supports a decision that the proposal may benefit from an integrated NEPA/LCA analysis. Professional judgement must be exercised in reaching a finàl determination to either include or reject an integrated NEPAVLCA analysis. A response of "No" to all three tests supports a determination that an integrated NEPA/LCA analysis is definitely not justified.

\section{ADVANTAGES, LIMITATION, AND APPLICABILITY}

Figure 1 provides a general-purpose tool that can be applied to a broad array of proposals. The tool is designed to provide a rigorous, systematic, and defensible approach in making such determinations. Undeniably, this tool does not eliminate subjectivity inherent in such determinations. However, the tool does provide a valuable methodology for reducing the vast number of factors that practitioners and decisionmakers might be

- inundated with as they ponder such issues.

\section{CONCLUSION}

Prudence must be exercised in determining the appropriateness of combining a LCA analysis with the NEPA planning process. It appears that an integrated NEPA/LCA analysis should be limited to a narrowly focused process or portion of the NEPA action under investigation. Because NEPA is initiated during the early planning process, a review should be conducted to determine if sufficient data exists to support any LCA that might be conducted. Such an investigation might be warranted when there is a strong likelihood that the integrated analysis could lead to improved decisionmaking.

As depicted in Figure 1, a series of six tests are intended to provide the user with objective criteria to assist the user in reaching a decision to integrate a LCA with a NEPA analysis. These tests do not completely eliminate subjectivity. Professional experience must still be exercised in reaching a final determination to incorporate an integrated NEPA/LCA analysis. 


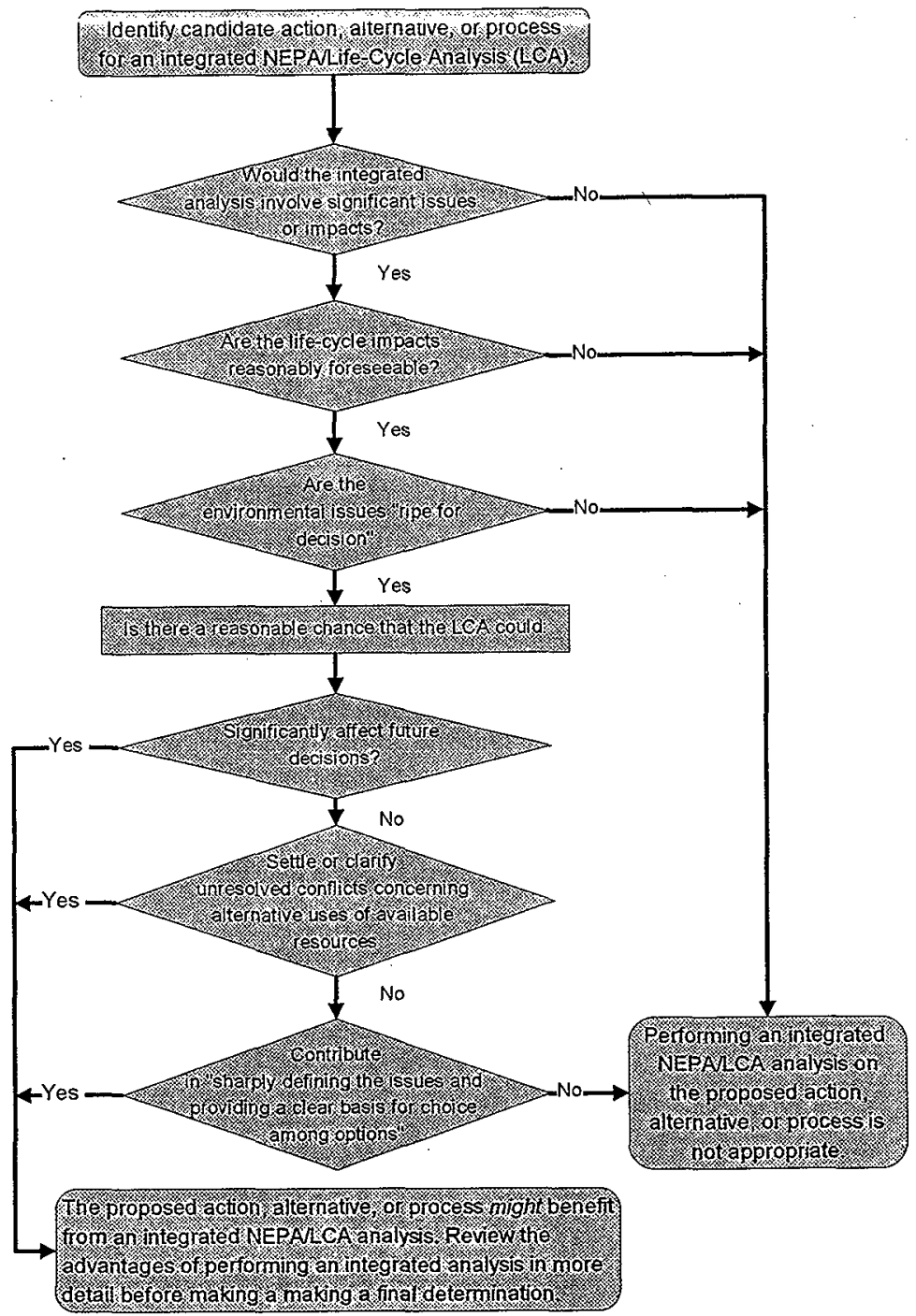

Figure 1. Methodology for Determining Under what Circumstances it is Appropriate to Combine an ISO-14040 LCA with a NEPA Analysis. 


\section{REFERENCES}

1 The National Environmental Policy Act of 1969, as amended (Pub. L 91-190, 42 U.S.C. 4321-4347, January 11970.

${ }^{2}$ Public law 91-190, 42 USC 4321-4347, Section 102[2][C], January 1, 1970.

340 Code of Federal Regulationis (CFR) 1508.9 [a][1].

${ }^{4} 40$ CFR 1502.4[b], 1502.20, 1508.28 .

${ }^{5} 40$ CFR $1500.1(\mathrm{c})$

${ }^{6} 40$ CFR $1500.2(\mathrm{e})$

740 CER 1500.2(f)

${ }^{8} 40$ CFR $1500.1(\mathrm{c}), 1500.4(\mathrm{f}), 1501.2,1502.1,1502.5,1502.14$

${ }^{9}$ Section 102(2)(E) of the NEPA Act.

1040 CFR 1502.14 


\section{ATTACHMENT}

WMH-9856226

Letter Report on Status of Activities Supporting National Environmental Policy Act Integration With The International Organization For Standardization - ISO 14000 Standard 


\section{Waste Management Federal Services of Hanford, Inc.}

P.O. Box 700

Richiand, WA 99352-0700

August 6, 1998

WMH-9856226

Mr. R. C. Brunke, Manager

Environmental Protection

Fluor Daniel Hanford, Inc. H6-21

Post Office Box 1000

Richland, Washington 99352-1000

Dear Mr. Brunke:

LETTER REPORT ON STATUS OF ACTIVITIES SUPPORTING NATIONAL ENVIRONMENTAL POLICY ACT INTEGRATION WITH THE INTERNATIONAL ORGANIZATION FOR STANDARDIZATION - ISO 14000 STANDARD

To support implementation of Presidential Executive and U.S. Department of Energy Orders, an analysis was completed recently under the Hanford Environmental Management Program (R1A63). The practical applicability of integrating the National Environmental Policy Act (NEPA) of 1969 with the International Organization for Standardization (ISO) 14000 Standard was analyzed. This effort was directed at addressing unresolved questions concerning the integration of NEPA with the Life-Cycle Assessment (LCA) direction as specified in ISO 14040. This issue was recently the focus of a special panel discussion at the June 1998 National Association of Environmental Professionals Annual Conference.

The analysis "Integrating a Life-Cycle Assessment with NEPA: Does it Make Sense?" addresses the significant progress made to date towards resolving this unsettled question. The issue of integrating NEPA with a LCA to provide a practical tool that can assist in determining when integration might be appropriate was reviewed.

If you have any questions, please feel free to contact me on 373-8119 or Mr. C. H. Ecclelston on 376-9364.

Very truly yours,<smiles>C1#CCCCCC1</smiles>

A. G. Weiner, Manager

Environmental Management Services

$\operatorname{sim}$

Attachment 


\section{CORRESPONDENCE DISTRIBUTION COVERSHEET}

Author
A. G. Weiner, WMH
C. H. Eccleston, 376-9364

Addressee

R. C Brunke, FDH
Correspondence No.

WMH-9856226

LETTER REPORT ON STATUS OF ACTIVITIES SUPPORTING NATIONAL Subject: ENVIRONMENTAL POLICY ACT INTEGRATION WITH THE INTERNATIONAL ORGANIZATION FOR STANDARDIZATION - ISO 14000 STANDARD

\section{DISTRIBUTION}

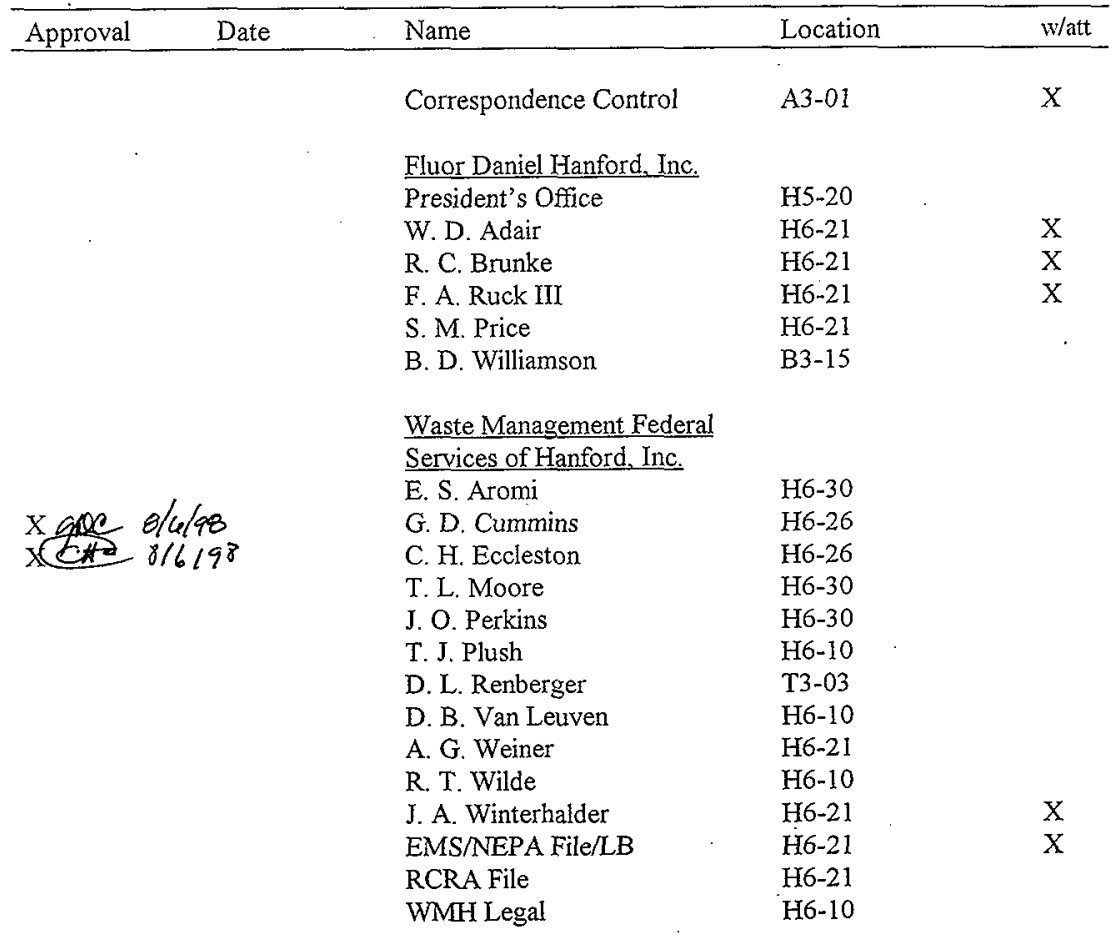

